DOI 10.37882/2223-2974.2020.11.16

\title{
СУБСИДИАРНАЯ ОТВЕТСТВЕННОСТЬ ЛИЦ, КОНТРОЛИРУЮЩИХ ДОЛЖНИКА
}

\section{SUBSIDIARY LIABILITY OF PERSONS CONTROLLING THE DEBTOR}

\section{S. Klimov}

Summary: In this article, we will consider the concept of subsidiary liability of persons controlling the debtor during the bankruptcy procedure. Let's analyze the concept of «real controlling person». We classify types of subsidiary liability based on the current legislation.

Keywords: person controlling the debtor, real controlling person, subsidiary liability of persons controlling the debtor, types of subsidiary liability.
$\mathrm{B}$ качестве одного из способов защиты прав участников гражданских отношений во время процедуры банкротства можно считать возможность привлечения лица контролирующего должника к ответственности.

Во время использования механизма привлечения к субсидиарной ответственности используются нормы, предусмотренные как законом о несостоятельности (банкротства), так и законов корпоративного права. Это указывает на слияние законодательных актов пересекающихся сфер.

В первую очередь ответственность лиц, контролирующих должника при его банкротстве предусмотрена с целью защиты кредиторов. Законодательно это реализуется с помощью двух механизмов указанных в Федеральным законе от 26.10.2002 № 127-Ф3 «О несостоятельности(банкротстве) (далее - Ф3 о банкротстве) в статье 10:

1. Статья 10 пункт 2 Ф3 о банкротстве устанавливает, что за нарушение обязанности по подачи заявления должника в арбитражный суд с сроки и в случаях, предусмотренных статьёй 9 лицо, контролирующее должника, может быть привлечено к субсидиарной ответственности;

2. Пунктом 4 статьи 10 ФЗ о банкротстве предусмотрено привлечение к субсидиарной ответственности в случаях действий (бездействий) которые привели к несостоятельности должника.

В случае с первым пунктом заявление можно подать во время конкурсного производства. Заявление может подано конкурсным управляющим либо по решению со- бранию кредиторов, представителя работника должника, самим работником, бывшем работником или уполномоченным органом, либо по своей инициативе.

Что касается случаев, относящихся ко второму пункту то заявление, может быть подано конкурсным управляющим.

Анализируя институт правового регулирования субсидиарной ответственности, можно прийти к выводу, что институт в настоящее время только развивается. Это связано и с попытками законодателей дать механизмы защиты добросовестным кредиторам.

Одна из попыток глобального реформирования института субсидиарной ответственности произошла в 2013 году (Федеральный закон от 28.06.2013 № 134-Ф3 «О внесении изменений в отдельные законодательные акты Российской Федерации в части противодействия незаконным финансовым операциям»). В качестве результата мы увидели появление презумпций контролирующих лиц, направленные на облегчение процесса доказывания в делах о банкротстве. Кроме того, появилось положение, которое позволяет до завершения расчетов с кредиторами с помощью промежуточного судебного акта устанавливать вину лица контролирующего должника, а вопросы о размерах ответственности оставить на рассмотрении в следующих этапах процесса.

Еще более глобальное и серьёзное реформирование института субсидиарной ответственности произошло в 2016 году (Федеральный закон от 28.12.2016 № 488-Ф3 «О внесении изменений в отдельные законодательные акты Российской Федерации»). В этот период был внесён 
ряд важных изменений относительно применения ФЗ о банкротстве.

Несмотря на внимание законодателей к данному вопросу, всё еще остаются проблемы в судебной практике.

Если смотреть на субсидиарную ответственность с гражданско-правовой точки зрения. То можно сказать, что субсидиарная ответственность это один из видов имущественной ответственности, к которой привлекается лицо, контролирующее должника, в дополнение к ответственности самого должника.

Множество дискуссий вызывает природа субсидиарной ответственности лиц, контролирующих должника.

Егоров А. и Усачёва К. считают, «законодатель конструирует субсидиарную ответственность контролирующих лиц при банкротстве, вкладывая совершенно иное содержание в термин «субсидиарная». ... Отныне это ответственность виновного лица не перед кредитором, а перед должником, конкурсной массе которого (и - опосредованно - всем его кредиторам) виновное лицо причинило ущерб. И ответственность эта существует в режиме, дублирующем традиционную деликтную ответственность»

По мнению Егорова А. и Усачёва К. «субсидиарная ответственность несет в себе существенную угрозу для стабильности оборота, поскольку из-за недостатков правового регулирования велик риск ее применения во всех случаях неудачного ведения бизнеса юридическим лицом, вследствие чего конструкция юридического лица, в котором участники не несут ответственности по его долгам, окажется разрушенной»

Мифтахутдинов Р. разделяет данную точку зрения. Согласно данной точки зрения, ответственность по п.4 ст. 10 ФЗ о банкротстве - это по своей сути больше возмещение убытков, чем классическая субсидиарная ответственность.

По мнению Мифтахутдинова Р. такая ответственность не имеет нечего общего с ответственностью общей части гражданского законодательства.

Мнение Ломакина Д. и Гентовта О. противоположено. Они считают, что «ответственность контролирующего лица сконструирована именно как ответственность перед кредиторами корпорации по обязательствам последней. Контролирующие лица не отвечают перед должником, за счет их имущества лишь пополняется конкурсная масса юридического лица, которая, в свою очередь, распределяется в установленном законом порядке между кредиторами. Таким образом, активы контролирующих лиц служат цели удовлетворения тре- бований кредиторов, перед которыми отвечает юридическое лицо. Тот факт, что такое имущество включается в конкурсную массу должника, свидетельствует лишь об особом порядке реализации механизма привлечения к ответственности контролирующих лиц, установленном Законом о банкротстве».

Савиных В. в своей работе пишет, что «субсидиарная ответственность возникает там и тогда, где наличествует особое экономическое содержание отношений сторон, состоящее в том, что субсидиарный должник обязуется к исполнению чужого долга в качестве санкции за свое противоправное поведение».

Автор в своей работе предлагает «пересмотреть проблему правовой сущности субсидиарной ответственности и определить, выступает ли она самостоятельным правовым институтом как разновидность гражданско-правовой ответственности или же является неким правовым режимом, который способен охватывать обязательства различной правовой природы».

Хочу отметить в завершение анализа, литературные источники разбивают субсидиарную ответственность на несколько видов:

- Внутренняя субсидиарная ответственность;

- Внешняя субсидиарная ответственность;

- Индивидуальная субсидиарная ответственность;

- Коллективная субсидиарная ответственность.

Хотелось бы дать пояснения видам субсидиарной ответственности, встречающемся в литературе.

В случаях, когда действия (бездействия) лица контролирующего должника повлекло за собой убытки, отражающиеся на конкурсной массе, это следует классифицировать как внутренняя ответственность.

Когда действия (бездействия) лица контролирующего должника повлекло за собой убытки непосредственно для кредиторов, это следует относить к внешней ответственности.

Классифицируя оба понятия, следует использовать в качестве критерия то, чему именно были причинены убытки действиями (бездействиями) лица контролирующего должника.

Следующие две классификации, следует рассматривать по другим критериям, а именно кем предъявляются требования.

Если требование будет предъявлено конкретным кредитором, то это следует классифицировать как индивидуальную. 
В случаях предъявления требований группой кредиторов, либо лицом уполномоченным группой, то это коллективная ответственность.

В настоящее время имущественная ответственность лиц, контролирующих должника, также разделяется на виды.

Если рассмотреть виды ответственности, которые указаны в ст. 10 Ф3 о банкротстве, то можно увидеть следующее.

Согласно п. 2 ст. 10 ФЗ о банкротстве, к субсидиарной ответственности возможно привлечь лицо, которое было обязано подать заявление в арбитражный суд, по требованиям, которые возникли после пропуска срока на подачу такого заявления, предусмотренного ст. 9 Ф3 о банкротстве. Как писалось ранее, эту ответственность можно классифицировать как классическую субсидиарную ответственность.

Ответственность лиц контролирующих должника за несоблюдение сроков направления заявления в арбитражный суд вытекает из такого понятия как добросовестность участника гражданско-правовых отношений, предусмотренных ст. 1, 10 ГК РФ.

Анализируя причины привлечения к ответственности за несоблюдение сроков направления заявления в арбитражный суд, для начала следует определить круг лиц привлекаемы к субсидиарной ответственности.

В соответствии с п. 2 ст. 10 ФЗ о банкротстве, в первую очередь привлекаются лица официально занимающие руководящие должности, это относиться как действующим руководителям, так и к тем, кто более им не является. Привлечение бывших руководителей имеет свои нюансы и критерии, однако это также практикуется.

Одним из важных вопросов остается возможность привлечения к ответственности лиц, реально контролирующих должника (бенефициары, реальные директора).

Нарушения рассматриваемые в п. 2 ст. 10 ФЗ о бан- кротстве, а также в п. 4 ст. 10 того же закона, подразумевает причинение вреда кредиторам. В этой связи будет логичным расширить смысл п. 2 ст. 10 с целью получения возможности привлечь лиц, реально контролирующих должника.

Такая точка зрения высказывается Егоровым А.

К лицам реально контролирующих должника следует относить юридических и физических лиц, которые юридически не являются органом управления или его членом, но фактически могут и оказывают влияния на действия (бездействия) должника.

Действующее законодательство расширяет круг лиц, которых можно привлечь к субсидиарной ответственности. Согласно Ф3 о банкротстве, к субсидиарной ответственности можно привлечь любое лицо, контролирующее должника.

Согласно п. 6 ст. 10 Ф3 о банкротстве, к контролирующим лицам следует относить лица, к которым предъявлены требования путем подачи в отношении них заявлений в арбитражный суд.

В завершение рассмотрения вопроса хотелось бы ещё раз более подробно классифицировать виды субсидиарной ответственности.

Согласно действующему законодательству, субсидиарная ответственность бывает следующих видов:

- Ответственность за несвоевременную подачу, вызванную действиями (бездействиями) лица контролирующего должника, заявления в арбитражный суд в сроки и в случаях, предусмотренных ст. 9 ФЗ о банкротстве;

- Ответственность лиц, контролирующих должника которые в силу своих действий (бездействий) привели должника к признанию его банкротом (п. 4 ст. 10 Закона о банкротстве);

- Ответственность лиц, контролирующих должника за причинение должнику убытков, приведших его к признанию несостоятельным (п. 3 ст. 531 ГК РФ).

\section{ЛИТЕРАТУРА}

1. Субсидиарная ответственность: экономическое содержание и правовая сущность (Савиных В. А.) (Вестник ВАС РФ 12-2012).

2. Субсидиарная ответственность по обязательствам должника в процессе банкротства: вопросы правоприменения (Суворов Е.Д.) («Закон», 2013, N 12).

3. Субсидиарная ответственность контролирующих должника лиц: эволюция законодательных подходов (Голубцов В.Г.) («Вестник Пермского университета. Юридические науки», 2020, N 2)

4. Требования связанных с должником лиц в деле о его банкротстве: от объективного к субъективному вменению (Суворов Е.Д.) («Вестник экономического правосудия Российской Федерации», 2019, NN 4, 5).

5. Доктрина «снятия корпоративного покрова» как инструмент распределения рисков между участниками корпорации и иными субъектами оборота (Егоров А.В., Усачева К.А.) (СПС «КонсультантПлюс»).

6. Субсидиарная ответственность в делах о банкротстве как самостоятельная (основная) ответственность контролирующего должника лица за нарушение 
обязанности действовать добросовестно и разумно по отношению к кредиторам подконтрольного лица (Морхат П.М.) («Вестник Арбитражного суда Московского округа», 2019, N 4).

7. «Предпринимательское право России: итоги, тенденции и пути развития: монография» (отв. ред. Е.П. Губин) («Юстицинформ», 2019).

8. Ответственность контролирующих лиц: правовая природа и механизм привлечения к ней (Ломакин Д., Гентовт 0.) (Хозяйство и право. 2016. № 1).

9. Субсидиарная ответственность в законодательстве о юридических лицах: необходимость реформ (Гутников 0.В.) («Адвокат», 2016, N 9).

10. Правовая логика возложения убытков на контролирующих лиц (Монастырский Ю.Э.) («Журнал российского права», 2019, N 2).

11. Основания ответственности контролирующего лица: проблемные аспекты установления состава правонарушения в свете реформирования российского законодательства о банкротстве (Жукова Ю.Д., Павлова К.П.) («Гражданское право», 2018, N 1).

12. Ответственность контролирующих должника лиц при несостоятельности (банкротстве) (Шиткина И.) («Хозяйство и право», 2017, N 8).

13. Ответственность контролирующих должника лиц при несостоятельности (банкротстве) (лекция в рамках учебного курса «Предпринимательское право») (Шиткина И.С.) («Предпринимательское право». Приложение «Право и Бизнес», 2017, N 4).

14. Правовое регулирование субсидиарной ответственности контролирующих должника лиц (Быков В.П., Черникова Е.В.) («Современное право», 2018, N 5).

15. Имущественная ответственность контролирующих должника лиц при банкротстве: очередные законодательные новеллы (Шиткина И.) («Хозяйство и прав0», 2017, N 11).

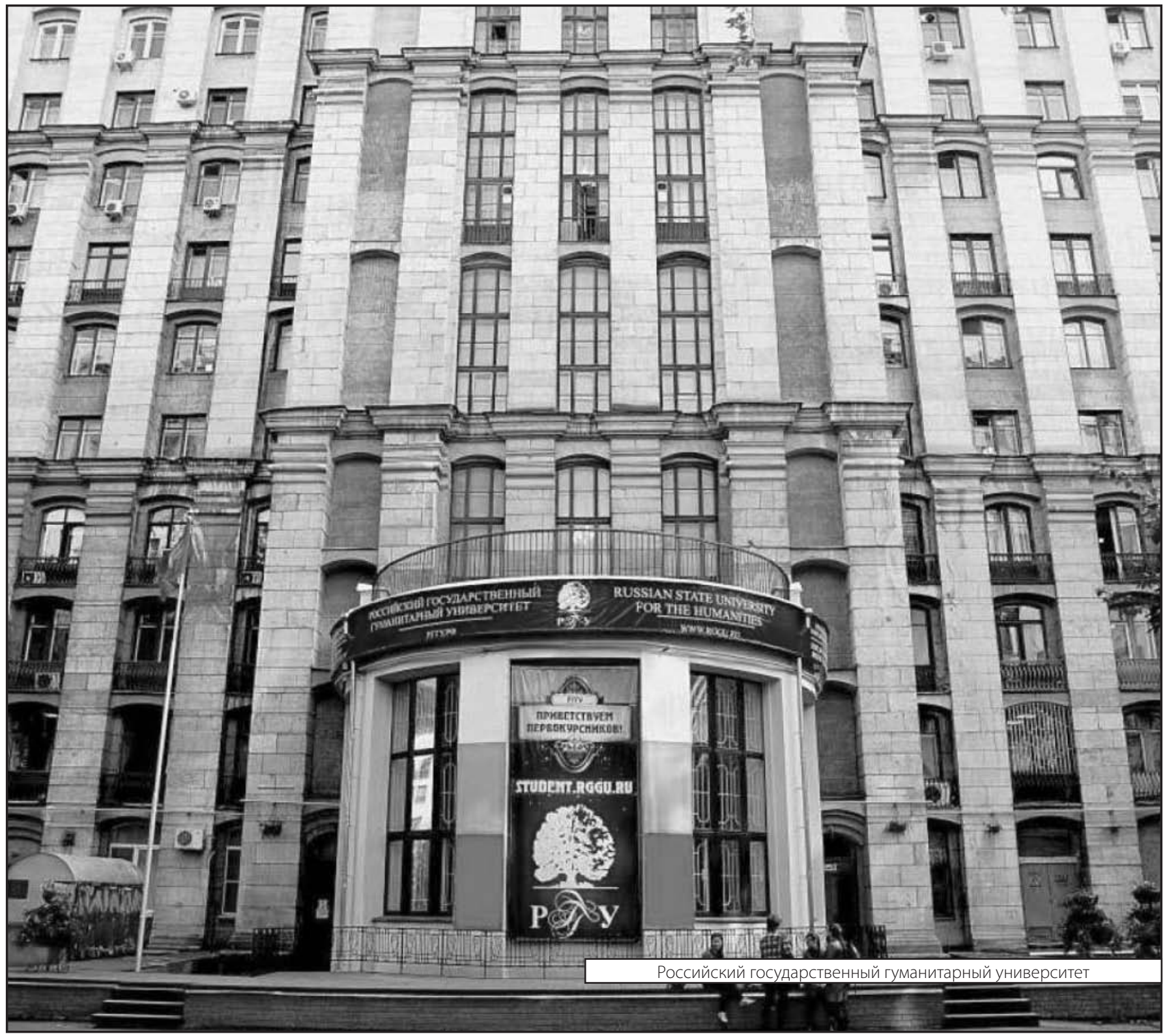

